\title{
Decoupled water and iron enrichments in the cratonic mantle
}

\author{
DR. LUC DOUCET, PHD ${ }^{1}$, YONGJIANG XU ${ }^{2}$, DELPHINE \\ KLAESSENS $^{3}$, HEJIU HUI ${ }^{4}$, DMITRI IONOV ${ }^{5}$ AND NADINE \\ D MATTIELLI $^{6}$ \\ ${ }^{1}$ Curtin University \\ ${ }^{2}$ Nanjing University \\ ${ }^{3} \mathrm{CRPG}$ \\ ${ }^{4}$ School of Earth Sciences and Engineering, Nanjing University \\ ${ }^{5}$ Géosciences Montpellier, Université de Montpellier \\ ${ }^{6}$ Université Libre de Bruxelles \\ Presenting Author: luc-serge.doucet@curtin.edu.au
}

Water and iron are believed to be key constituents controlling the strength and density of the lithosphere and, therefore, play a crucial role in the long-term stability of cratons. On the other hand, metasomatism can modify the water and iron abundances in the mantle and possibly triggers thermo-mechanical erosion of cratonic keels. Whether local or large scale processes control water distribution in cratonic mantle remains unclear, calling for further investigation. Spinel peridotite xenoliths in alkali basalts of the Cenozoic Tok volcanic field sampled the lithospheric mantle beneath the southeastern margin of the Siberian Craton, and the absence of garnet-bearing peridotite amongst the xenoliths suggests that the craton margin, in contrast to the central part, lost its deep keel. The Tok peridotites experienced extensive and complex metasomatic reworking by evolved, CaFe-rich liquids that transformed refractory harzburgite to lherzolite and wehrlite. We used polarized Fourier transform infrared spectroscopy (FTIR) to obtain water content in olivine, orthopyroxene (opx), and clinopyroxene (cpx) of 14 Tok xenoliths. The cores of the pyroxene grains, unlike olivine, experienced no water loss due to dehydration or addition attributable to interaction with the host magma. The Tok opx has less water than previously studied opx from the central Siberian craton. Melting models suggest that the water contents of Tok peridotites are higher than in melting residues, and argue for a post-melting (metasomatic) origin.

The water contents in opx and cpx of Tok peridotites are decoupled from iron enrichments or other indicators of melt metasomatism. Such decoupling is not seen in the Udachnaya and Kaapvaal peridotites but is similar to observations on Tanzanian peridotites. Our data suggest that iron enrichments in the southeastern Siberian craton mantle preceded water enrichment. Pervasive and large-scale, iron enrichment in the lithospheric mantle may strongly increase its density and initiate a thermo-magmatic erosion. By contrast, the distribution of water in xenoliths is relatively "recent" and was controlled by local metasomatic processes that operate shortly before the volcanic eruption. Hence, water abundances in minerals of Tok mantle xenoliths appear to represent a snapshot of water in the vicinity of the xenolith source regions. 